\title{
Erratum to: What influences 11-year-olds to drink? Findings from the Millennium Cohort Study
}

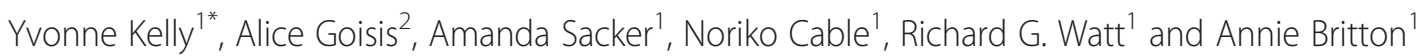

\section{Erratum}

In the publication of this article [1], the Acknowledgements section failed to include the following:

"The alcohol use and attitudes variables in MCS5 were co-funded by grant AA013606 from the U.S. National Institute on Alcohol Abuse and Alcoholism".

\section{Author details}

'Department of Epidemiology and Public Health, University College London, London WC1E 6BT, UK. ${ }^{2}$ Department of Social Policy, The London School of Economics and Political Science (LSE), Houghton Street, London WC2A 2AE, UK.

Published online: 18 August 2016

\section{Reference}

1. Kelly $Y$, et al. What influences 11-year-olds to drink? Findings from the

Millennium Cohort Study. BMC Public Health. 2016;16:169.

doi:10.1186/s12889-016-2847-x.

\footnotetext{
*Correspondence: y.kelly@ucl.ac.uk

'Department of Epidemiology and Public Health, University College London, London WC1E 6BT, UK

Full list of author information is available at the end of the article

Submit your next manuscript to BioMed Central and we will help you at every step:

- We accept pre-submission inquiries

- Our selector tool helps you to find the most relevant journal

- We provide round the clock customer support

- Convenient online submission

- Thorough peer review

- Inclusion in PubMed and all major indexing services

- Maximum visibility for your research

Submit your manuscript at www.biomedcentral.com/submit 